\title{
Um Novo Capítulo
}

No dia 6 de Janeiro foi escolhida a nova direcção da SPQ para o triénio 2010-2012. A eleição dos actuais corpos gerentes fez-se em Assembleia Geral convocada para o efeito, seguindo os procedimentos estatutários estabelecidos.

Todo o ambiente que rodeou esta passagem de testemunho foi de grande serenidade, característico de uma instituição quase centenária que se tem sabido gerir autonomamente, seguindo um caminho próprio, sem servilismos, nem procurando o sensacionalismo mediático.

Com maior ou menor visibilidade, a SPQ tem prosseguido a missão que se propôs realizar e tornou pública na cerimónia de inauguração da então nova sede, na Av. da República, em 24 de Fevereiro de 1977: constituir um centro de debate franco e cordial que estimule e promova o contacto entre os seus membros de forma a contribuir para o desenvolvimento da investigação e para um melhor ensino da Química. São estes os objectivos que ainda hoje figuram nos Estatutos.

Em 2009, por força das circunstâncias, a SPQ (com as outras 3 socie-

\section{Presidência:}

Presidente: Mário Nuno Berberan (IST)

Vice-Presidente: Maria José Calhorda (FCUL)

\section{Conselho Executivo:}

Secretário-Geral: Joaquim Faria
(FEUP)

dades científicas que partilhavam os espaços da Av. da República) viu-se obrigada a mudar de instalações. A alteração de localização não foi grande, pois foi possível encontrar novo andar na mesma avenida e até no mesmo quarteirão, apenas alguns números acima (passámos do 37 para o 45). Talvez por isso o acontecimento não teve grande impacto. Os sócios estão habituados à pacatez das pequenas transições e isso dá-lhes uma agradável sensação de segurança. $\mathrm{E}$ com placidez se têm habituado a ver os anos a passar... e de repente já são quase 100 !

Em 28 de Dezembro de 2011 a nossa Sociedade completará 100 anos, curiosamente no mesmo ano que todo o mundo celebrará o Ano Internacional da Química. Talvez seja uma boa altura para agitar as águas e para levar a mais importante e antiga sociedade científica portuguesa a muito mais pessoas do que aos seus cerca de 2200 sócios.

Mostrar ao cidadão comum o verdadeiro impacto da Química nas suas vidas e fazê-lo perceber que ela está presente em todas as actividades do dia-a-dia. Fazer entender que a ciên-

\section{Composição dos Órgãos Eleitos}

Secretário-Geral Adjunto: Adrian Silva (FEUP)

Secretário-Geral Adjunto: Marcela Segundo (FFUP)

Tesoureiro: Maria Manuel Marques (FCT-UNL)

Mesa da Assembleia Geral:

Presidente: Baltazar Castro (FCUP) cia central é e continuará a ser muito mais parte da solução do que do problema. Trazer a Química para primeiro plano. Retomar o químico como profissional dotado de um conhecimento especializado, capaz de manter a sua perícia científica através de um desenvolvimento profissional contínuo. Talvez a ambição seja demasiada, mas 100 anos de vida merecem um sonho condigno.

Para terminar, não podemos senão, genuína e sentidamente, agradecer à direcção cessante o trabalho feito e acima de tudo terem chegado até aqui, assegurando esta preciosa continuidade. Assim consigamos nós dar conta da tarefa que nos foi agora confiada.

P’la Direcção

\section{O Secretário-Geral} Joaquim Faria

*****

$1^{\circ}$ Secretário: Ana Cristina Freire (FCUP)

$2^{\circ}$ Secretário: Ricardo Franco (FCT$-\mathrm{UNL})$

Conselho Fiscal:

Presidente: Artur Silva (DQ-UA)

$1^{\circ}$ Secretário: Ana Cavaleiro (DQ-UA)

$2^{\circ}$ Secretário: Diana Pinto (DQ-UA) 